\title{
ПРАВО НА ДОСТУП К СПРАВЕДЛИВОМУ СУДЕБНОМУ РАЗБИРАТЕЛЬСТВУ В СЛУЧАЕ НЕСОСТОЯТЕЛЬНОСТИ СТОРОНЫ АРБИТРАЖНОГО СОГЛАШЕНИЯ
}

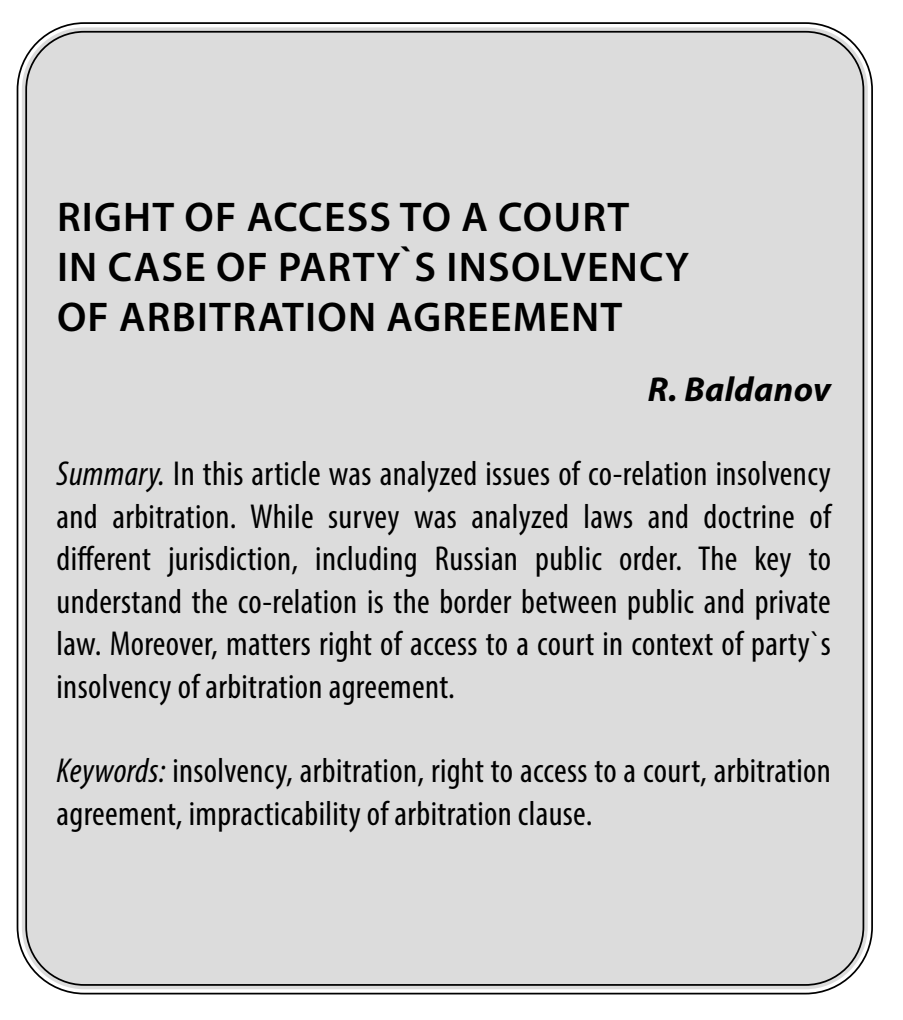

B процессуальной доктрине и правоприменительной практике не существует единого мнения относительно судьбы арбитражной оговорки в случае несостоятельности одной из сторон арбитражного соглашения. Постановление Пленума ВАС № 35 от 22.06.2012 вносит определенную ясность, закрепляя принцип концентрации споров. Кроме того, существуют иные процессуальные аспекты, обусловленные процедурой банкротства, например необходимость уведомления об обращении в арбитражный суд с иском о признании лица несостоятельным [13, с. 146-149]. Между тем остается открытым вопрос: что делать, если признан несостоятельным сам носитель нарушенного права?

Следует отметить, что третейское разбирательство по своей натуре противопоставимо производству по делам о несостоятельности. Если третейское разбирательство носит децентрализованный характер и является квинтэссенцией частного права, то несостоятельность характеризуется централизованным порядок разрешения и рассмотрения споров [19].

\author{
Балданов Руслан Владимирович \\ ФГБОУ ВО «Уральский Государственный \\ Юридический Университет», г. Екатеринбург \\ Ruslanbaldanov@gmail.com
}

Аннотация. В статье проанализированы подходы к пониманию проблемы соотношения несостоятельности и третейского разбирательства. В ходе исследования были проанализированы как положения закона различных юрисдикций, так и доктринальные положения отечественного правопорядка. Ключом к пониманию соотношения является ответ на вопрос 0 том, где пролегает граница между частным и публичным правом. Кроме того, особую роль играет право на справедливое судебное разбирательство в контексте квалификации оговорки в качестве исполнимой несостоятельным истцом.

Ключевые слова: несостоятельность (банкротство), третейское разбирательство, право на доступ к справедливому судебному разбирательству, арбитражная оговорка, неисполнимость арбитражной оговорки.
Наиболее явно эта разница выражается в делах, где несостоятельным признан ответчик. Исходя из необходимости проверки арбитражным судом, который рассматривает дело о банкротстве, требований кредиторов к должнику третейский суд признается не имеющим компетенции (т.н. принцип концентрации). В настоящей работе не мы не будем рассматривать обоснованность такого вывода, но заострим внимание именно на несостоятельности истца.

\section{Ранее проводившиеся исслеАования}

Ранее исследователями производился анализ зарубежных правопорядков на эту тему [3]. Если вкратце, то в немецкий правопорядок признает право несостоятельного лица на обращение в государственный суд, если у несостоятельного истца не хватает денег на уплату третейских сборов и пошлин. Арбитражная оговорка в таком случае признается неисполнимой в силу нехватки денежных средств. Федеральный Верховный суд Германии указал, что от несостоятельной стороны не требуется обоснования ее отказа от испол- 
нения арбитражного соглашения, поскольку недостаточность денежных средств сама по себе презюмирует неисполнимость арбитражного соглашения [18].

Английский же правопорядок последовательно отстаивает проарбитражную позицию, даже если сторона арбитражного соглашения признана несостоятельной [16]. Однако вопрос о несении расходов, связанных с третейским разбирательством, остается открытым юрисдикция не нашла ответа на этот вопрос. При этом суды называют «фантастической» ситуацию, при которой все расходы должен нести платежеспособный ответчик [17].

Как указывалось выше, мнения по вопросу исполнимости арбитражного соглашения в условиях несостоятельности стороны, разделились. В.А. Волгина приходит к выводу о том, что экономическое обстоятельство становится угрозой реализации права на доступ к правосудию и праву на справедливое судебное разбирательство [3]. Аналогичной позиции придерживается и Гузанов К.А.[4, С. 72-78].

Константин Антонюк же придерживается иной позиции, полагая, что неисполнение арбитражных соглашений (в т.ч. по мотивам несостоятельности) противоречит международным обязательствам России по признанию арбитражных соглашений участников оборота [1, С. 45]. Эта позиция также поддерживается Усоскиным С.В. [15], Мурановым А.И. [6].

Полагаю, позиция сторонников неисполнимости арбитражного соглашения наиболее обоснована, поскольку в большей мере отвечает экономическим реалиям. Кроме того, позиция может быть аргументирована не только с экономической, но и с правовой позиции.

\section{Право на Аоступ к правосу ию} и несостоятельность сторОны

В настоящее время судебная практика в России идет по следующему пути: факт нахождения коммерческой организации в тяжелом финансовом состоянии не может сам по себе свидетельствовать о том, что арбитражное соглашение неисполнимо, а также не обязывает государственный суд рассматривать по существу заявленный иск [7].

Однако вопрос об исполнимости арбитражного соглашения зависит не только от возможности несения расходов, но также связан с публичными интересами. КС РФ отмечал, что принцип эффективной интерпретации арбитражной оговорки перестает действовать, когда создается угроза публичным интересам [10]. Каким же образом могут ущемляться публичные инте- ресы в условиях несостоятельности должника? Одной из основ публичного порядка является защита охраняемых законов интересов третьих лиц, в случае с несостоятельностью - защита прав и интересов конкурсных кредиторов [8]. Кроме того, о публично правовой природе несостоятельности неоднократно указывал как ВС РФ [9], так и КС РФ [1 1]. Невозможность должника получить доступ к третейскому разбирательству, безусловно, влечет вред интересам конкурсных кредиторов.

Таким образом, несостоятельный оказывается на своеобразном перепутье, где ему всюду закрыты дороги: арбитражный суд не станет рассматривать иск ввиду наличия пророгационного соглашения, третейский суд не станет рассматривать иск в связи с отсутствием финансирования.

Какое же содержание имеет право на доступ к правосудию? Как указывается в литературе, право на доступ к правосудию находится в системе правовых гарантий права на судебную защиту. При отсутствии свободного и беспрепятственного доступа к судебной защите механизм защиты нарушенных прав человека остается обездвиженным [12].

Вместе с тем гарантии защиты нарушенных прав теряют свои смысл без фактической возможности воспользоваться ими. То есть под доступом к правосудию понимается именно беспрепятственная возможность передачи любого спора о гражданских права на рассмотрение суда (или третейского суда) [2].

То есть отказ в рассмотрении спора о гражданских правах является ущемлением права на доступ к справедливому судебному разбирательству, исходя из толкования ЕСПЧ.

Таким образом, отказ в рассмотрении иска несостоятельного должника государственным арбитражным судом при невозможности оплатить третейские взносы и сборы для рассмотрения иска компетентным третейским судом противоречит основополагающей идее о предоставлении доступа к правосудию и судебной защите.

\section{Варианты решения проблемы}

Выше была поставлена проблема, из которой видится следующие варианты выхода.

\section{1. Корректировка арбитражной оговорки в альтернативную}

Судебной практикой уже была выработана позиция относительно признания и приведения решений тре- 
тейского суда в условиях несостоятельности ответчика. Аргументация заключается в том, что несостоятельность представляет собой часть публичного порядка (в чем заключается содержание публичного порядка применительно к несостоятельности, мы писали выше), а, следовательно, решение третейского суда будет неминуемо отменено государственным судом в рамках контроля последних над первыми.

Однако описанный подход касается несостоятельности ответчика, в условиях несостоятельности истца полагаем, что справедливым будет не прекращение действия арбитражной оговорки, а ее трансформация в альтернативную. Таким образом, несостоятельный истец может обратиться как в государственный, так и в третейский суд.

Критика названного варианта может быть сформулирована следующим образом.

Путем предоставления права предъявления иска в государственный суд, мы уничижаем волю сторон при заключении арбитражного соглашения. Таким образом, нарушается принцип «расtum sunt servanda». Иначе говоря, арбитражная оговорка трансформируется в отсутствие каких-либо пороков или соглашения сторон. Кроме того, пороки финансового состояния лица не должны влиять на право.

Между тем несостоятельность представляет собой экстраординарную ситуацию, которую сложно предвидеть как с точки зрения экономики, так и с точки зрения права. Трансформация оговорки в альтернативную равным образом уничижает волю сторон, как уничижается воля однополых супругов, брак которых не признается в России. Пороки финансового состояния неминуемо влияют на право и весь институт несостоятельности тому подтверждение (Например, особые правила оспаривания сделок. Привлечение к субсидиарной ответственности участников, членов совета директоров, аудиторов, а также иных лиц, которые из буквального текста закона не несут ответственность по долгам несостоятельного). Следовательно, данные возражения бессодержательны.

Кроме того, арбитражная оговорка остается действительной, она лишь трансформируется в альтернативную. Такая трансформация призвана не допустить правовую неопределенность. В противном случае нарушается право лица на справедливое судебное разбирательство.

Таким образом, полагаю, что в случае признания истца несостоятельным он имеет право обратиться не только в третейский суд, но и в государственный.
Такая трансформация оговорки продиктована необходимостью дать лицу доступ на справедливое судебное разбирательство, предоставить фактический доступ к правосудию, независимо от его финансового положения.

\section{2. Проведение собрания кредиторов, на котором должен быть разрешен вопрос о финансиро- вании третейского разбирательства или об от- чуждении права требования}

Поскольку несостоятельный истец не может нести расходы на третейское разбирательство, возможно финансирование третьим лицом, в частности, конкурсным кредитором. Полагаю, что данный вопрос должен быть разрешен на собрании кредиторов, поскольку судьба дебиторской задолженности неминуемо влияет на права конкурсных кредиторов.

На собрании также может быть поставлен вопрос об отчуждении права требования несостоятельного. Например, конкурсный кредитор может приобрести такую дебиторскую задолженность в обмен на право требования к должнику. Такая схема реализована в рамках судьбы права требования о привлечении к субсидиарной ответственности [14].

Возможность разрешения данного вопроса путем проведения собрания продиктована уже частно правовой стороной несостоятельности. Поскольку несостоятельность хоть и имеет публичные корни, она также имеет и частно правовые вкрапления. Следовательно, невозможно запретить дееспособным лицам распоряжаться правом требования в своей воле и своем интересе (п. 2 ст. 1 ГК РФ). Между тем такой способ не будет соответствовать принципу процессуальной экономии.

Во-первых, дополнительные денежные траты - для уведомления о созыве собрания на ЕФРСБ, а также на проведение торгов.

Во-вторых, публикацию о созыве собрания необходимо публиковать не менее, чем за 14 дней до даты собрания. Следовательно, созыв собрания повлечет также дополнительные временные траты.

В-третьих, право требования, которое не подтверждено решением третейского суда может быть реализовано по цене, которая значительно ниже номинальной цены.

Кроме того, предложенный вариант не решает поставленную проблему исполнимости арбитражной оговорки в условиях несостоятельности истца. Более того, такой вариант лишь затягивает процедуру отчуждения 
права требования и влечет дополнительные расходы, поэтому от него надлежит отказаться.

\section{ВывО $\triangle \mathrm{b}$}

Таким образом, наиболее логичным и обоснованным видится трансформация арбитражной оговорки в альтернативную, то есть появления у несостоятельного истца права на предъявление иска в государственный суд. Обоснование такому пути дано выше, между тем, резюмируем его здесь в качестве вывода.

1. Невозможность предоставления несостоятельному защиты в государственном или третейском суде влечет за собой невозможность несостоятельного обратиться к механизму судебной защиты своих гражданских прав, то есть нарушает несостоятельного на доступ к правосудию.
2. Для устранения правовой неопределенности и устранения проблема в регулировании предлагается предполагать, что вместе с признанием лица несостоятельным оговорка становится альтернативной. Альтернативная оговорка наделяет несостоятельного правом на обращение в государственный или третейский суд по его выбору. При этом если третейский суд откажет в возбуждении третейского разбирательства в связи с неуплатой сборов, то у несостоятельного останется возможность инициировать разбирательство в государственном суде.

3. Альтернативность оговорки позволяет избежать, с одной стороны, признания недействительной арбитражной оговорки в отсутствие правовых оснований, а с другой позволяет обеспечить доступ к правосудию.

\section{ЛИТЕРАТУРА}

1. Констатин Антонюк. Исполнимость арбитражных соглашений в случае банкротства стороны спора: куда движется судебная практика? // Arbitration. ru № 9 (13). 2019. C. 45.

2. Т.Г. Бородинова. Право граждан на свободный доступ к правосудию: понятие, содержание, субъекты // Общество: политика, экономика, право. 2017.

3. В.А. Волгина. Влияние нехватки денежных средств на исполнимость арбитражного соглашения // Опыты цивилистического исследования. Выпуск 3. Статут. 2019.

4. К.А. Гузанов. К вопросу об исполнимости арбитражного соглашения в спорах с участием организаций, находящихся в стадии конкурсного производства // Вестник арбитражной практики. 2018. № 1. С. 72-78.

5. Зарубина М.Н., Катукова С.Ю. Принцип эффективной интерпретации третейского соглашения // Вестник гражданского процесса. 2018. № 4. С. 267278.

6. А.И. Муранов. Факт тяжелого финансового положения стороны — коммерческой организации не может сам по себе свидетельствовать 0 неисполнимости арбитражного соглашения. Комментарий к определению ВС РФ от 12 июля 2017 года № 307-ЭС17-640 // Вестник экономического правосудия Российской Федерации. 2017. № 10.

7. Определение ВС РФ от 12.07.2017 по делу № А56-13914/2016; Определение ВС РФ от 13.05.2021 по делу № А40-31546/2020; Постановление АС у0 от 05.11.2020 по делу № $\mathrm{A} 50-33179 / 2019$.

8. Определение ВСРФ от 09.10.2015 по делу № А41-36402/2012.

9. Определение ВСРФ от 16.11.2020 № 308-ЭС20-11632.

10. Постановление Конституционного Суда РФ от 26.05.2011 № 10-П;

11. Постановление КС РФ от 22.07.2002 № 14-П, Постановление КС РФ от 19.12.2005 № 12-П, Определение КС РФ от 17.07.2014 № 1675-0, 0пределение КС РФ от 25.09.2014 № 2123-0.

12. Постановление ЕСПЧ от 21.02.1975 года. По делу «Голдер против Соединенного Королевства» // Европейский суд по правам человека: избранные решения в 2 томах /отв. ред. В.А. Туманов. М., 2000. С. 39-80.

13. Раздьяконов, Е.С. Процессуальные последствия досудебных уведомлений в делах о банкротстве // Международный научно-исследовательский журнал. 2020. № 8(98) ч. 2. С. 146-149. D0I: 10.23670/IRJ2020.98.8.062.

14. Федеральный Закон № 127 «0 несостоятельности (банкротстве)».

15. С.В. Усоскин. Отсутствие средств на оплату арбитража - не повод для игнорирования арбитражной оговорки, кроме крайне исключительных случаев. // Третейский суд. 2017. № 3.

16. http://www.cisarbitration.com/2020/10/26/arbitrability-of-insolvency-disputes-the-principle-of-modified cE7UNyubPT2EkLyvXFvXEzf20lj02V_QB8ikUPR2v0jrKW99x1c\%20 (дата обращения 08.04).

17. Janos Paczy v. Haenlder \& Natermann Gmb H.P. 309.

18. Judgment of 14 Sept. 2000, III ZR33/00 (German Bundesgerichtshof). CLOUT Case No. 404 (P. 8)

19. In re U.S. Lines, Inc., 197 F.3d 631, 640 (2d Cir. 1999).

( ) Балданов Руслан Владимирович (Ruslanbaldanov@gmail.com ).

Журнал «Современная наука: актуальные проблемы теории и практики» 